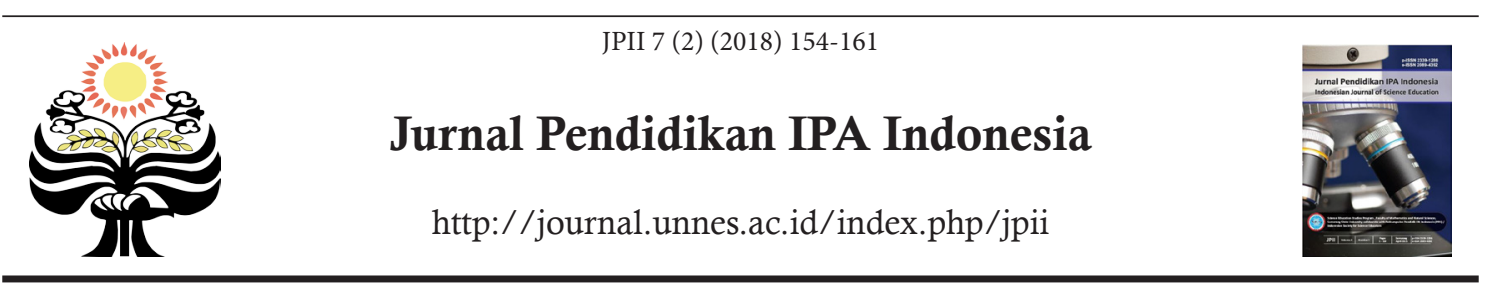

\title{
THE INFLUENCE OF ANDROID-BASED ISOMORPHIC PHYSICS (FORFIS) APPLICATION ON ANALOGICAL TRANSFER AND SELF-DIAGNOSIS SKILL OF STUDENTS AT SMA NEGERI 3 KUPANG
}

\author{
D. K. Sari*1, Supahar ${ }^{2}$, U. Ralmugiz ${ }^{3}$ \\ ${ }^{1}$ Physics Education, Post-Graduate Universitas Negeri Yogyakarta, Indonesia \\ ${ }^{2}$ Physics Education, Faculty of Mathematics and Natural Sciences, Universitas Negeri Yogyakarta, Indonesia \\ ${ }^{3}$ Mathematics Education, Universitas Muhammadiyah Kupang, Indonesia
}

DOI: 10.15294/jpii.v7i2.14268

Accepted: February $17^{\text {th }}, 2018$. Approved: May $9^{\text {th }}, 2018$. Published: June $30^{\text {th }}, 2018$

\begin{abstract}
This research intended to understand the effect of Isomorphic Physics (FORFIS) application to the analogical transfer and self-diagnosis skill of high school students. The use of Android applications in physics learning has given a considerable influence in improving the various abilities of learners. However, no one has measured the influence of the Android application on the analogical transfer and self-diagnosis skill of students, especially in physics subject. This research type was experimental research of pre-test post-test control group design. The subjects involved in this research were 1 physics teacher and 87 students of SMA Negeri 3 Kupang; 28 students in the experimental class I (G1), 35 students in the experimental class II (G2), and 24 students in the experimental class III (G3). The data obtained were analyzed using the ANOVA Mixed Design method in combination with General Linear Model. The results of the analysis show that the FORFIS application could improve 0.912 or $91.2 \%$ of the students' analogical transfer and self-diagnosis skill. Therefore, the FORFIS application employed in physics learning had a great influence on the improvement of analogical transfer and self-diagnosis skill of high school students.
\end{abstract}

(C) 2018 Science Education Study Program FMIPA UNNES Semarang

Keywords: isomorphic, physics, android, analogical transfer skill, self-diagnosis skill

\section{INTRODUCTION}

The involvement of technology in the educational environment requires creative and innovative educators in using technology in learning. Technological developments ultimately lead to changes in educational settings (Robinson \& Reinhart, 2014; Eliana et al., 2016; Wardani et al., 2017; Usmeldi et al., 2017). One of the devices that could be utilized for educational purposes is the Android-based smartphone (Calimag, et al., 2014). Interactive skills, easy access, and fun are some advantages provided by this device (Hanafi \& Samsudin, 2012). This causes lear-

*Correspondence Address

E-mail: desy.kumala2016@student.uny.ac.id ners having a tendency towards the use of the Android-based smartphone. The Android-based smartphones facilitate learners in accessing multimedia resources, and studying anytime and anywhere (González et al., 2015). The type of learning media that can be operated using this device is an Android-based learning app. The utilization of Android-based learning applications in education is one of the XXI Century learning styles (Calimag et al., 2014). Some research on the use of Android applications in physics learning gave very satisfactory results. The use of Android applications in physics learning could improve the ability of mathematical representation and the interpretation of electrical circuits (Yadiannur \& Supahar, 2017), learning independence, conceptual understanding (Arista \& Kuswanto, 2018), 
independent thinking skills, and High Order Thinking Skills (Mardiana \& Kuswanto, 2017). These studies provided very important information on the use of Android applications in physics learning.

The use of Android applications in physics learning has a considerable effect on the improvement of the students' various abilities. However, the use of Android apps in physics learning has not been measured its influence on the analogical transfer and self-diagnosis skill of students. One of the Android apps that could be utilized to measure the analogical transfer and self-diagnostic skill is the Android-based Isomorphic Physics (FORFIS) application. The FORFIS application is an Android-based learning media that I developed myself. The application contains isomorphic questions that refer to the indicators of analogical transfer skill. In addition, this application also carries three different problem features. All three features in the FORFIS application aims to provide repetition of problems on a regular basis so that learners can train their skills (Sari, 2018). The question features are the question examples, exercise questions, and quizzes that are isomorphic on Momentum and Impulse materials. The sample problems in the FORFIS application included in the discussion are in accordance with the problem-solving steps. The problems contained in this application have been declared worthy of use both to train and measure the analogical transfer skill. Although it has been developed, this application has not been tested to determine its influence in improving the ability of learners.

The analogical transfer skill defines as an ability to transfer familiar problem-solving knowledge to solve new problems (Docktor \& Mestre, 2014; Eysenck \& Keane, 2010; Lin \& Singh, 2013 ${ }^{\mathrm{a}}$; Lin $\&$ Singh, 2013 ${ }^{\text {b }}$ Mason, et al., 2009; Monaghan et al., 2015; Robertson, 2017; Santrock, 2011; Stevenson, et al., 2013; Storm \& Bui, 2016). The transferring activities have continuously happened even though there are differences in each problem features (Casale, et al., 2012). Though the problem is different, the resolution process has the same steps (Eysenck \& Keane, 2010; McBridge \& Cutting, 2016). Thus, the analogical transfer could define as an ability to solve new problems using the acquired knowledge. Furthermore, the self-diagnosis skill is a learner's ability to identify and explain selfmade errors (Yerushalmi, et al., 2008; Yerushalmi et al., 2012). In addition, Putri et al. (2015) defined the self-diagnosis skill as a diagnosing or identifying process of the conditions within one- self. The diagnosed object in practicing the selfdiagnosis skill is a solution to solve problems that have been answered by their own (Safadi, 2017). The self-diagnosis skill in this study defines as a process of identifying and explaining errors of the examined problem-solving steps.

In relation with the analogical transfer skill, the results of the study conducted by Brokes et al. (2011) provide information that giving the problem-solving exercise to the student on algebra and calculus programs could improve their analogical transfer skill. Furthermore, the research related to the self-diagnosis skill has done by Yerushalmi et al. (2012). Through their research, we know that students' value of the self-diagnosis skill correlates with problem-solving skills. The performance of self-diagnosis could influence the success in transferring knowledge towards the encountered problems. This means that the analogical transfer skill influences the self-diagnosis skill.

High school students have a tendency to transfer their knowledge to new problems and diagnose mistakes that have been made. This information was obtained from interviews with some high school teachers in Kupang city, and observations conducted at several senior high schools in Yogyakarta. The students' tendency appeared when they were asked to solve physics problems. While solving the same problem as the given example, most students were able to finish well. However, when the given problem has little difference in the problem-solving steps, most students experienced difficulty. The difficulties the students experienced arose because of the paradigm that the final answer is the sole purpose of problem-solving. Therefore, it is important to do research related to learning media that could be utilized to improve the analogical transfer skill and self-diagnosis skill.

The solution offered to help students overcome their tendency is providing practice questions containing indicators of analogical transfer. The goal is to train students' analogical transfer skill and, indirectly, self-diagnosis skill. The questions given could be obtained from various sources. One of the learning media that include the problems having the indicators of analogical transfer is the FORFIS application. The previous research by Brokes et al. (2011), employed exercise questions with paper and pencils method, while in this research the method used was categorized by the current technological development. Therefore, this research utilized Android app as a learning media. This application was compared with the learning media usable for teachers i.e., handouts and whiteboards. Thus, the focus of this 
study was to analyze the influence of FORFIS Application in improving the analogical transfer and self-diagnosis skill of high school students.

\section{METHODS}

This research employed quasi-experiment method with pre-test post-test control group design(Abdurrahman, et al., 2018). The research was conducted at SMA Negeri 3 Kupang, East Nusa Tenggara. The research subjects involved in this study were 1 physics teacher, 28students in theexperimental class I (G1), 35 students in the experimental class II (G2), and 24 students in the experimental class III(G3). The design of this study is presented in Figure 1.

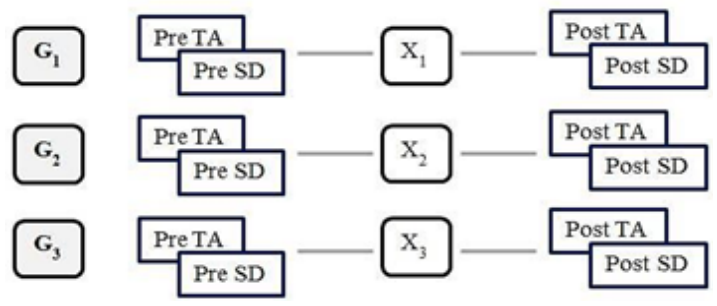

Figure 1. The Research Design of Pre-Test PostTest Control Group Design

Each experimental class was given different media. The experimental class I (G1) used theFORFIS app, the experimental class II (G2) employed a handout, while the experimental class III (G3) utilized the blackboard as a medium. However, all three classes obtained the same topic. The difference took place in the way of obtaining questions.

The data of analogical transfer and selfdiagnosed skill were obtained from the analogical transfer skill pre-test (PreTA) and post-test (PosTA), as well as self-diagnosis skill pre-test (PreSD) and PostSD. The research began with the PreTA followed by PreSD. The PreSD activities were performed by diagnosing mistakes when answering PreTA questions. Data analysis technique employed was Anova Mixed Design in combination with General Linear Model. This analysis technique was called Anova Mixed Design as it combines two sub-analysis. This technique was used to test the difference in the group score 1 (pre-test vs. post-test) and the group score 2 (G1, G2, G3). Therefore, the analysis technique adopted was also called the Anova Mixed Design $2 \times 3$. The purpose of adopting this technique was to analyze the influence of media usage in such learning. Prior to the analysis, the data normality and homogeneity were examined. The data normality was tested using the Kolmogorov-Smirnov test which stated that the data was declared normal if the sig. $>0.05$. The data homogeneity test employed the Levene test which categorized data as homogeneous if the sig. $>0.05$. The data analysis using the Anova Mixed Design in combination with General Linear Model in this research only considered the influence of media usage in learning. The results obtained were seen on partial eta square values. The greater the value of partial eta square, the greater the influence of media used in learning.

\section{RESULTS AND DISCUSSION}

This research used the FORFIS application as learning media. The purpose of using the FORFIS application was to find out the influence of FORFIS application in improving the analogical transfer and self-diagnosis skill. The learning activities carried out by the teacher using a scientific and lecturing approach in combination with demonstrations and exercises. After the teacher presented the provided materials, then $\mathrm{s} /$ he used the existing media to each experimental class to rehearse the students' analogical transfer and selfdiagnosis skill. The learning activities were conducted three times, and the learning steps were split up into three stages of introduction, core, and closing. The PreTA and PreSD were carried out at the introduction stage. The core learning activities adopted the scientific approach consisting of observing, asking, trying, reasoning, and communicating. The use of the FORFIS application in learning lied in the trying and reasoning part. The students were asked to work on the exercise questions and quizzes contained in the FORFIS application. After the three meetings were held, the students were then given the PosTA followed by the PostSD.

This study intended to determine the influence of FORFIS application on the analogical transfer and self-diagnosis skill of high school students. Prior to the analysis, the data normality and homogeneity test were carried out. In short, the significance values of normality and homogeneity test results are presented in Table 1 . The information in Table 1 is the data of PreTA, PreSD, PostTA, and PostSD results in each experimental class showing the significance value of normality test which was greater than 0.05 . This means that the overall data obtained from the research results were normally distributed. The significance value of homogeneity test results from PreTA, PreSD, PostTA, and PostSD in each experimental class 
was also greater than 0.05 , which means that the overall research data had the same variance. The research result data that have been stated normal and homogeneous then were analyzed to know the influence of media used in physics study.

Table 1. The Significance Value of the Obtained Data's Normality and Homogeneity Test

\begin{tabular}{cccc}
\hline \multirow{2}{*}{ Class } & Type of Research & $\begin{array}{c}\text { Sig. } \\
\text { Normality Test }\end{array}$ & $\begin{array}{c}\text { Sig. } \\
\text { Homogeneity Test }\end{array}$ \\
\hline \multirow{2}{*}{$G_{1}$} & PreTA & 0.176 & 0.149 \\
& PreSD & 0.129 & 0.533 \\
& PostTA & 0.104 & 0.236 \\
& PostSD & 0.353 & 0.102 \\
\cline { 2 - 4 } & PreTA & 0.087 & 0.719 \\
$\mathbf{G}_{2}$ & PreSD & 0.120 & 0.414 \\
& PostTA & 0.090 & 0.226 \\
& PostSD & 0.159 & 0.412 \\
\cline { 2 - 4 } & PreTA & 0.489 & 0.893 \\
$\mathbf{G}_{3}$ & PreSD & 0.249 & 0.250 \\
& PostTA & 0.115 & 0.408 \\
& PostSD & 0.228 & 0.589 \\
\hline
\end{tabular}

The analysis results of the increase in the students' analogical transfer skill are presented in Figure 2. It tells that the students' early analogical transfer skills in each experimental class tended to be the same. The similarity of the initial analogical transfer skill of students was because the three experimental classes were the leaded classes for the science majors. After utilizing different media in each experimental class, such skill has increased significantly. It appears in Figure 2 that the students' analogical transfer skill in the class using FORFIS application (G1) was higher than that using handout (G2) and whiteboard (G3), while both (G2) and (G3) were likely to be the same. This means that of the three media applied in the lesson, the most effective was the FORFIS application.

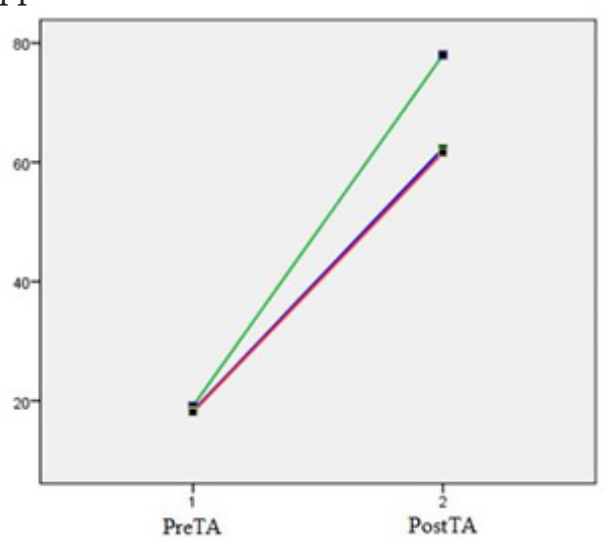

Figure 2. The Increase of Analogical Transfer Skill Graph
Next, the results of the self-diagnostic skill enhancement analysis are presented in Figure 3. The information provided is that the students' prior self-diagnosis skill in each experimental class was likely to be the same. However, after using different media in each experimental class, the students' self-diagnosis skills have increased significantly. This is presented in Figure 3, the students' self-diagnosis skill after learning using FORFIS application (G1) was higher than that using handout (G2) and whiteboard (G3), while both (G2) and (G3) did not differ significantly. This indicates FORFIS application was the most effective instructional media to improve the students' self-diagnosis skill compared to the others.

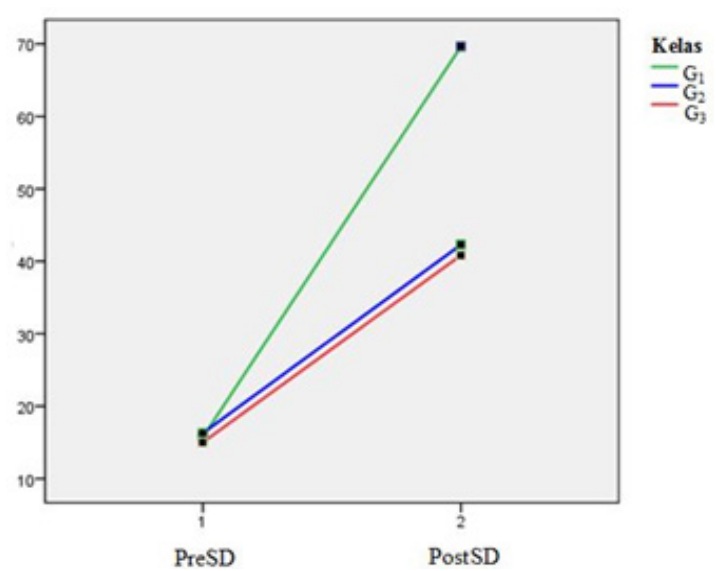

Figure 3. The Increase of Self-Diagnosis Skill Graph 
The use of FORFIS application in physics learning showed a considerable increase compared to using other media. Various conveniences such as helping in solving problems, beneficial in learning to make learning more interesting and motivating students for improvement. The students' response to the ease of the FORFIS application was very well. The use of FORFIS application in learning could help students solve physics problems. The students' response to the benefits of using Isomorphic Physics application in learning showed that they need FORFIS application in classroom learning. In addition, the students also considered the FORFIS application as interesting learning media and motivate them to learn. The ease the FORFIS application provided has triggered an increase in the analogical transfer and selfdiagnosis skill. Thus, it concluded that the use of FORFIS application in learning could significantly increase the analogical transfer and self-diagnosis skill.

Furthermore, the analysis results of the instructional media influence in each experimental class are presented in Table 2. If two dependent variable groups are used, the multivariate significance appears in the Hotelling's Trace. Whereas, if more than 2 groups of dependent variables are employed, the multivariate significance appears in the Wilks' Lambda. Partial Eta Squared's value describes the Effect Size or how much influence/contribution was given to improve the analogical transfer and self-diagnosis skill of the learners. Table 2 shows that there were four dependent variables involved in the PreTA, PreSD, PostTA, and PostSD, with three experimental classes. Therefore, multivariate significance appeared in the Wilks' Lambda (Ghozali, 2013). It informs that the use of FORFIS application media devoted 0.912 or $91.2 \%$ in improving the students' analogical transfer and self-diagnosis skill. Moreover, the use of handout media contributed 0.868 or $86.8 \%$, and the use of whiteboard gave 0.819 or $81.9 \%$. The FORFIS application in learning contributed enormously. That was due to the FORFIS application content including examples, exercises, and quizzes that were isomorphic problems. The examples in the discussion are in accordance with the problem-solving steps. The problems contained in the FORFIS application indirectly improved the analogical transfer and self-diagnosis skill. Although the overall experimental class has improved, the ease of obtaining learning source was also an improving factor in each experimental class. The FORFIS application made it easy for students to get a learning resource as it was installed on their personal smartphone so they could learn at any time and place. The contribution given by each experiment class was quite high. Thus, of the three media used in learning, the FORFIS application devoted most in improving the students' analogical transfer and self-diagnosis skill.

Table 2. The Analysis Results of the Media Usage Influence on the Analogical Transfer and Self-Diagnosis Skill

\begin{tabular}{ccccc}
\hline Class & F & Sig. & $\begin{array}{c}\text { Partial Eta } \\
\text { Squared }\end{array}$ \\
\hline $\mathrm{G}_{1}$ & $\begin{array}{c}\text { Wilks' } \\
\text { lambda }\end{array}$ & $2.841 \mathrm{E2}^{\mathrm{a}}$ & .000 & .912 \\
$\mathrm{G}_{2}$ & $\begin{array}{c}\text { Wilks' } \\
\text { lambda }\end{array}$ & $1.793 \mathrm{E2}^{\mathrm{a}}$ & .000 & .868 \\
& $\begin{array}{c}\text { Wilks' } \\
\mathrm{G}_{3}\end{array}$ & $1.239 \mathrm{E} 2^{\mathrm{a}}$ & .000 & .819 \\
\hline
\end{tabular}

In addition, the analysis was done separately to determine the effect of media on each variable. The data analysis results are presented in Table 3. This analysis involved two dependent variables i.e., the PreTA and PostTA. Therefore, the significance emerged in the line of Hotelling's Trace (Ghozali, 2013). It tells that the use of FORFIS application in improving the analogical transfer skill of students devoted 0.895 or $89.5 \%$, the use of media handouts contributed 0.856 or $85.6 \%$, and the use of whiteboard media granted 0.800 or $80.0 \%$. Based on Table 3, it indicates that the FORFIS application was more influential than other media. This great influence was due to the isomorphic problems with the completion step according to the indicators of analogical transfer contained in the FORFIS application. Isomorphic problem-solving indirectly trained students' analogical transfer skill. In other words, the FORFIS application devoted most in improving the students' analogical transfer skill. 
Table 3. The Analysis Results of the Media Usage Influence on the Analogical Transfer Skill

\begin{tabular}{|c|c|c|c|c|}
\hline Class & & $\mathbf{F}$ & Sig. & $\begin{array}{c}\text { Partial Eta } \\
\text { Squared }\end{array}$ \\
\hline $\mathrm{G}_{1}$ & $\begin{array}{l}\text { Hotel- } \\
\text { ling's } \\
\text { trace }\end{array}$ & $7.155 \mathrm{E} 2^{\mathrm{a}}$ & .000 & .895 \\
\hline $\mathrm{G}_{2}$ & $\begin{array}{l}\text { Hotel- } \\
\text { ling's } \\
\text { trace }\end{array}$ & $4.993 \mathrm{E} 2^{\mathrm{a}}$ & .000 & .856 \\
\hline $\mathrm{G}_{3}$ & $\begin{array}{l}\text { Hotel- } \\
\text { ling's } \\
\text { trace }\end{array}$ & $3.353 \mathrm{E} 2^{\mathrm{a}}$ & .000 & .800 \\
\hline
\end{tabular}

The analysis results of the media usage influence on the students' self-diagnosis skill are presented in Table 4. This analysis involved the PreSD and PostSD. In accordance with the terms given, the significance of the analysis result emerged in the Hotelling's Trace. Table 4 informs that the use of FORFIS application in improving the students' self-diagnosis skill granted 0.817 or $81.7 \%$, the use of handouts contributed 0.565 or $56.5 \%$, the use of whiteboard devoted 0.468 or $46.8 \%$. Table 4 provides information that the use of the Isomorphic Physics application had a greater impact that the use of other media. That was because the FORFIS application contains examples, exercises, and quizzes. Through the example, the students could find how to solve a problem. The exercises given with the answers were to compare the students' result of the problem with the example. The quizzes trained students to correctly answer the given questions. These there content indirectly trained students to diagnose their mistakes in solving problems. In sum, the FORFIS application contributed most to improve the students' self-diagnosis skill.

Tabel 4. The Analysis Results of the Media Usage Influence on the Self-Diagnosis Skill

\begin{tabular}{ccccc}
\hline Class & & $\mathbf{F}$ & Sig. & $\begin{array}{c}\text { Partial Eta } \\
\text { Squared }\end{array}$ \\
\hline $\mathrm{G}_{1}$ & $\begin{array}{c}\text { Hotelling's } \\
\text { trace }\end{array}$ & $3.750 \mathrm{E} 2^{\mathrm{a}}$ & .000 & .817 \\
$\mathrm{G}_{2}$ & $\begin{array}{c}\text { Hotelling's } \\
\text { trace }\end{array}$ & $1.090 \mathrm{E} 2^{\mathrm{a}}$ & .000 & .565 \\
$\mathrm{G}_{3}$ & $\begin{array}{c}\text { Hotelling's } \\
\text { trace }\end{array}$ & $73.756^{\mathrm{a}}$ & .000 & .468 \\
\hline
\end{tabular}

Based on the analysis results of the media usage influence, it concluded that the use of FORFIS application granted a considerable influence in improving the students' analogical transfer and self-diagnosis skill. The experimental class adopting the FORFIS application ranked first, followed by the (G2) and (G3) which respectively adopted handouts and whiteboards.

The use of FORFIS application in physics learning gave a noticeable effect in improving the analogical transfer and self-diagnosis skill of the learners. Based on the learners' response to the use of FORFIS application in learning, they said that the app helped them solve problems, was useful in learning, made learning more interesting and motivated. The various facilities offered by the FORFIS application in learning were known through a questionnaire response given to the 28 students joined in the (G1). Their response to these various factors was very good. This statement was strongly approved by 22 students, which means that the Isomorphic Physics application was very easy for learners in solving encountered physics problems. Moreover, there were 27 students who stated that the application was very useful, indicating that the students needed the FORFIS application in the learning process. In addition, there were 27 students who agreed that the FORFIS application is interesting, and 23 of them believed that the app could motivate them. The more they were motivated, the more knowledge they would acquire. Hence, the FORFIS application was greatly improved the students' analogical transfer and self-diagnosis skill.

The effect of using FORFIS application in learning provided a large partial eta square value. That was due to the features provided by this application aims to improve the students' analogical transfer and self-diagnosis skill. The question featured with isomorphic problems referring to the indicators of analogical transfer skill. This type of problem was available in example questions, exercise questions, and quizzes. The students who were diligent in working on the problems contained in the application gradually formed the analogical transfer in accordance with the problem-solving steps provided. Therefore, the application was said to be the learning media that helped improve the analogical transfer skill with a great influence of $89.5 \%$. In addition, the use of FORFIS application in learning could also improve the student' self-diagnosis skill with a considerable influence that was $81.7 \%$. However, the FORFIS application did not influence the selfdiagnosis immediately. Increasing the self-diagnosis skill was closely related to the increased the 
analogical transfer skill (Yerushalmi et al., 2012). The results of the analysis showed that partial eta values of the use of FORFIS application in improving the analogical transfer and self-diagnosis skill were not much different. It proved that these two skills were connected. Thus, it concluded that the use of FORFIS applications in learning gave a considerable influence on the students' analogical transfer and self-diagnosis skills.

The use of the Android application in physics learning provided various facilities for the learners to obtain learning resources (Hanafi\&Samsudin, 2012). By utilizing the trends that millennial learners have in this digital age, educators are easier in implementing learning both inside and outside the classroom. Learners no longer need to bring a lot of resources in the form of a textbook. Only by bringing the Android-based smartphone, students could have learning resources. These conveniences offered help learners to learn at anytime and place. Thus, the use of Android-based learning applications in the world of education is the XXI century learning style. This statement is supported by the research results conducted by Calimag et al. (2014).

\section{CONCLUSION}

This study was conducted to determine the influence of FORFIS application usage in Physics learning on the students' analogical transfer and self-diagnosis skill. The influence was measured either individually or both kind of skills. The results showed that the FORFIS application devoted enormously in improving the students' analogical transfer and self-diagnosis skill. The Isomorphic Physics application also greatly contributed to each skill individually. Therefore, the FORFIS application used in physics teaching in schools had a major effect on improving the students' analogical transfer and self-diagnosis skill.

\section{REFERENCES}

Abdurrahman, A., Saregar, A., \& Umam, R. (2018). The Effect of Feedback as Soft Scaffolding on Ongoing Assessment toward the Quantum Physics Concept Mastery of the Prospective Physics Teachers. Jurnal Pendidikan IPA Indonesia, 7(1), 34-40.

Arista, F. S., \& Kuswanto, H. (2018). Virtual Physics Laboratory Application Based on the Android Smartphone to Improve Learning Independence and Conceptual Understanding. International Journal of Instruction, 11(1), 1-16.
Brokes, D.T., Ross, B. H., \& Mestre, J. P. (2011). Specify, Transfer, and the Development Of Expertise. Physical Review Special Topics-Physics Education Research, 7(1), 1-8.

Calimag, J. A. N. N. V, Miguel, P. A. G., Conde, R. S., \& Aquino, L. B. (2014). Ubiquitous Learning Environment Using Android Mobile Application. IMPACT: International Journal of Research in Engineering \& Technology, 2(2), 119-128.

Casale, M. B., Roeder, J. L., \& Ashby, F. G. (2012). Analogical Transfer in Perceptual Categorization. Memory \& Cognition, 40(3), 434-449.

Docktor, J. L., \& Mestre, J. P. (2014). Synthesis of Discipline-Based Education Research in Physics. Physics Education Research, 20119(10), 1-58.

Eliana, E. D. S., Senam, Wilujeng I., \& Jumadi. (2016). Effectiveness of Project-Based E-Learning to Improve ICT literacy. Jurnal Pendidikan IPA Indonesia, 5(1), 51-55.

Eysenck, M. W., \& Keane, M. T. (2010). Cognitive Psychology: A Student's Handbook. Science (sixth edit). USA: Psychology Press.

Ghozali, I. (2013). Aplikasi Analisis Multivariate Dengan Program IBM SPSS 21. Semarang: Badan Penerbit Universitas Diponegoro.

González, M. Á., González, M. Á., Martín, M. E., Llamas, C., Martínez, Ó., Vegas, J., Hernández, C. (2015). Teaching and Learning Physics with Smartphones. Journal of Cases on Information Technology, 17(1), 31-50.

Hanafi, H. F., \& Samsudin, K. (2012). Mobile Learning Environment System ( MLES ): The Case Of Android-Based Learning Application on Undergraduates ' Learning. International Journal of Advanced Computer Science and Applications, 3(3), 1-5.

Lin, S.-Y., \& Singh, C. (2013 $)$. Challenges in Using Analogies. The Physics Teacher, 49, 512-513.

Lin, S. Y., \& Singh, C. (2013 $)$. Using an Isomorphic Problem Pair to Learn Introductory Physics: Transferring from a Two-Step Problem to a Three-Step Problem. Physical Review Special Topics-Physics Education Research, 9(2), 11-19.

Mardiana, N., \& Kuswanto, H. (2017). AndroidAssisted Physics Mobile Learning to Improve Senior High School Students' Divergent Thinking Skills and Physics HOTS. AIP Conference Proceedings, 1868. Retrieved from : https://doi. org/10.1063/1.4995181

Mason, A., Cohen, E., Singh, C., \& Yerushalmi, E. (2009). Self-Diagnosis, Scaffolding and Transfer: A Tale of Two Problems. AIP Conference Proceedings, 1179, 27-30.

McBridge, D. M., \& Cutting, J. C. (2016). Cognitive Psychology theory, process and methodology. SAGE Publications.

Monaghan, P., Sio, U. N., Lau, S. W., Woo, H. K., Linkenauger, S. A., \& Ormerod, T. C. (2015). Sleep Promotes Analogical Transfer in Problem Solving. Cognition, 143, 25-30. 
Putri, M. P. S., Sudirman, \& Pasaribu, A. (2015). Analisis Kesalahan dalam Menyelesaikan Soal Penerapan Fisika dengan Menggunakan Lembar Self-Diiagnosis pada Mahasiswa Pendidikan Fisika FKIP Universitas Sriwijaya. Jurnal Inovasi Dan Pembelajaran Fisika, 1(1), 7-14.

Robertson, S. I. (2017). Problem Solving: Perspectives from Cognition and Neuroscience (2nd ed). New York: Routledge.

Robinson, R., \& Reinhart, J. (2014). Digital Thinking and Mobile Teaching: Communicating, Collaborating \& Construction in an Access Age. Mylekha eBook.

Safadi, R. (2017). Self-Diagnosis as a Tool for Supporting Students' Conceptual Understanding and Achievements in Physics: The Case Of 8ThGraders Studying Force And Motion. Physics Education, 52(1), 14002.

Santrock, J. W. (2011). Educational Psychology. New York: Mc Graw Hill.

Sari, D. K. (2018). Pengembangan Aplikasi Fisika Isomorfis (FORFIS) Berbantuan Android untuk Meningkatkan Kemampuan Transfer Analogi dan Self-Diagnosis Peserta Didik SMA. Tesis. Yogyakarta: Program Pascasarjana Universitas Negeri Yogyakarta.

Stevenson, C. E., Heiser, W. J., \& Resing, W. C. M. (2013). Working Memory as a Moderator of Training and Transfer of Analogical Reasoning In Children. Contemporary Educational Psychology, 38(3), 159-169.
Storm, B. C., \& Bui, D. C. (2016). Individual differencesin Mind Wandering while Reading Predict Lower Rates of Analogical Transfer. Learning and Individual Differences, 51, 427-432.

Usmeldi, Amini, R., \& Trisna, S. (2017). The Development of Research-Based Learning Model with Science, Environment, Technology, and Society Approaches to Improve Critical Thinking Of Students. Jurnal Pendidikan IPA Indonesia, 6(2), 318-325

Wardani, S., Lindawati, L., \& Kusuma, S. B. W. (2017). The Development of Inquiry by Using Android-System-Based Chemistry Board Game to Improve Learning Outcome and Critical Thinking Ability. Jurnal Pendidikan IPA Indonesia, 6(2), 196-205.

Yadiannur, M., \& Supahar. (2017). Mobile Learning Based Worked Example in Electric Circuit (WEIEC) Application to Improve the High School Students' Electric Circuits Interpretation Ability. International Journal of Environmental and Science Education, 12(3), 539-558.

Yerushalmi, E., Cohen, E., Mason, A., \& Singh, C. (2012). What Do Students Do when Asked to Diagnose Their Mistakes? Does It Help Them? I. An Atypical Quiz Context. Physical Review Special Topics-Physics Education Research, 8(2), 020109.

Yerushalmi, E., Mason, A., Cohen, E., \& Singh, C. (2008, October). Effect of Self Diagnosis on Subsequent Problem Solving Performance. In AIP Conference Proceedings (Vol. 1064, No. 1, pp. 53-56). AIP. 